\title{
Global Education in English Classroom: Integrating Global Issues into English Language Teaching
}

\author{
Hendi Pratama and Yuliati
}

\begin{abstract}
Teaching is not all about how to make students master the subject and get high scores. It is also an effort to make a better world and to drive students to be much better citizens for the world. Seeing the current condition of the world, educators should show their social responsibilities to build it and to solve the global problems as well as to use education to foster peace and mutual understanding among people and nations. This turns to be a challenge for all educators including English language educators to transform their teaching and learning process into a process which does not only focus on equipping students to be successful learners of the target language or proficient speakers of certain languages. More than that, English teachers should be able to equip students to be more understanding and showing more respect to their surroundings. This paper aims at analyzing and explaining how to integrate education which focuses on global issues and problems into English Language Teaching. The analysis showed that peace, respect, understanding among people across nations can not only be built solely through diplomatic cooperation by the governments. These entity can be built effectively through education which reflect them by integrating some global issues to the teaching and learning process itself.
\end{abstract}

Index Terms - Global education, English, language teaching, global problems.

\section{INTRODUCTION}

As English teachers in this global era, we have some responsibilities to positively react to the critical issues have been occurring in the world. Our world is now facing worrying problems such as terrorism, ethnic clash, social discrepancy, and environmental destruction. We have to be able to prepare our students to deal with those problems with what so called as "Global Education [1], [2]."

Global Education is an approach to teaching and learning language which is intended to response some critical global issues. It is aimed at facilitating students to effectively and actively acquire certain languages they learn along with enriching them with knowledge, understanding, and commitment to positively respond global problems and related issues in the world as one of the world citizens. Global Education is considered to be education which supports knowledge, views, attitudes, and skills related to live life with high responsibilities for multicultural and interdependent world [3]. Another scholar defines global education as form of efforts to make changes to the content, method and related contexts of education system in the

Manuscript received March 29, 2015; revised June 29, 2015.

The authors are with the English Department, Languages and Arts Faculty, Semarang State University (UNNES), Indonesia (e-mail: yuliati.edu@gmail.com, hendi.edu@gmail.com) purpose of preparing students to be good world citizens [4].

By those definitions, it is clear that global educators focus on putting global education as the main part of pedagogical content and approach and not just considering it as one of techniques in teaching. There are at least four main areas or issues to consider as the basic parts of global education; "peace, human rights, development, and environment [1]."

The purposes of a global education cover four main areas; knowledge, skills, attitudes, and action. Knowledge related to global issues and problems comes first. Students will work for a better life and world when they know things related to the problems faced by the world, including the causes of those problems as well as the possible solutions. The second goal is skill. Students need to master the skills of communication, critical and logical thinking, creativity, and problem solving. Other skills such as peaceful resolution for clashes, informed decisive capability, and the skill to apply multiple perspectives in seeing a problem are essential to answer the global issues or problems. The third goal is global attitudes. This means students need to be equipped with the attitudes to be aware and curious to the global problems. Some other attitudes such as respect, appreciation, empathy, and justice are also important to uphold. The last goal is action. This refers to active participation to solve global issues and problems starting from the local problems up to the global ones.

Some discussions related to global problems and how to respond them are disclosed in the further sections. The discussion is followed by some examples for each point mentioned. Thus, it gives clear description and explanation related to the topic being discussed.

\section{TEACHING GlobAL ISSUES IN THE ENGLISH CLASSROOM}

As being mentioned previously, the responsibilities of foreign language educators are not only teaching vocabulary, grammar, pronunciation, listening, speaking, reading and writing. However, we as educators should also pay attention to some problems occurring in the world and equip our students with knowledge and skills to actively participate in solving the problems or at least showing sympathy to those issues. It is morally far from good to only stick our mind in teaching to the textbooks we are using without any care to the problems around us. We may not be able to solve those problems directly but our attention, sympathy, and understanding toward the situations and problems are essentials to reduce the spread of the problems.

In addition, we should realize that the profession of educators is to bring benefits to society. In the past 20 years, the growing of professionals in education and science was 
so massive. They conducted research for solving problems existed in their surroundings. Physicians, as one of examples, worked very hard for innovation and invention until they got Noble Prize Award. Lawyers also worked very hard to be contributive to the so called law enforcement. If language teachers truly want to be professions, they should start preparing themselves to show their social responsibilities to society.

Besides, education is one of fields considered to have strong contribution in spreading peace, justice, and solution to any social problems. The World Confederation of Organizations of Teaching Profession [5] clearly declares that its goals are to promote and create equality, peace, justice, freedom, and human rights among people [1]. The 1974 United Nations Education, Scientific, and Cultural Organization Recommendation Concerning Education for International Understanding, Cooperation and Peace and Education Relating to Human Rights and Fundamental Freedoms calls for global view on all level or degree of education and respect among cultures, understanding to the individual and group rights, and active participation in solving global problems [2].

As language educators, the most tangible action related to global problems is the UNESCO's Linguapax program. This name is derived from Latin language which means language (lingua) and peace (pax). This refers to language teaching for international understanding to promote peace. This Linguapax resulted some recommendations for foreign language educators [6] :

1) Knowing and understanding their responsibilities to also support international understanding in the teaching and learning process.

2) Effectively using the language teaching and learning process to increase respect, peace, and cooperation among countries in the world.

3) Developing international understanding through extracurricular activities such as international students exchange programs, activities, videos.

4) Developing the international cooperation among nations through students' cooperation in the classroom.

By this Linguapax, it is clear that the importance of equipping students with global knowledge is inevitable. The problems might not be around us or far from our surrounding but our effort to introduce our students to the issues occur all over the world have significant impact to the development of the world.

\section{INTEGRATING GLOBAL EDUCATION TO ENGLISH CLASSROOM}

EFL educators have already tried to integrate global problems and global education into the teaching and learning classroom. This includes some integration to the content, technique, teaching materials, lesson plan, teacher training programs, and some other activities such as extracurricular activities.

\section{A. Content Integration}

Integrating global education to the content of teaching and learning process can be done through listening, speaking, reading, and writing sources. Teachers can teach those four skills by using issues related to global issues such as international human rights, international peace, international health issues, or even any issues related to antiracism movements.

They may start with teaching listening to students by playing audios and videos related to how UN has been working so far to uphold human rights internationally and equality for all human being in the world. Reading sources can also use passages related to world issues. Another skills writing and speaking can follow the previous skills materials.

Teachers can also integrate global education into their teaching and learning materials by using some terminologies related to world issues. One of examples is the use of the world "peace" in teaching pronunciation or consonant " $p$ " in English classroom. Teaching grammar seems to be more interesting if the materials are challenging for the students. Teachers may use the progress of international human trafficking from then to now to teach present, past, and progressive tenses, for example.

This integration is intended to adapt the teaching and learning materials to be more related to the global issues. Besides this will enrich students' and teachers' knowledge related to problems occur worldwide as well as other issues related to it. In other words, both students and teachers can gain more benefits and added value from the adaptation.

\section{B. Methods of Teaching}

How we teach global education to students in the classrooms is another important factor. This motivates teachers and students to start using active learning instead of passive one. Besides, the teaching and learning process will be a student-centered teaching and ends up with the paradigm of teaching language for communication about world issues.

Some methods teachers may use in the classrooms are experimental learning, role play, and discussion, for examples. This may turn students to act as whites and darks to learn about apartheid or racism in the world. A more dynamic teaching and learning process can also be done by asking students to simulate UN ambassadors meeting simulation. Students act as the ambassadors of each member of UN.

Teachers can also bring the world into the classroom by asking students to act as the US ambassador for children and ask them to deliver speech as form of speaking class. Students can also do some project based learning activities by conducting simple interviews and surveys related to the role of UN to solve some international problems.

All of those methods above are aimed at giving students the description or picture of facing and solving world problems. In addition, the awareness of them related to the global problems will be raising. This might not directly solve the real problems but this create a better condition both for the students' development and the world condition in the future to be better.

\section{TEACHING MATERIAls FOR GlOBAL EDUCATION}

Global education is intended to introduce and expose students to knowledge, skills, and attitudes which will lead 
them to be more socially responsible as the citizens of the world. The textbooks available so far seems to have not touched these issues deeply. Even when they touch these issues, they do not put them as the priority but simply on the surface of the issues. Most textbooks are considered to be so tourist-minded with the focus more on topics related to shopping, fashions, travelling, holidays, and glamorous life styles and even it seems that they lead students to "bias, racism, and stereotype [7]."

Fortunately, not all foreign language textbooks neglect the global issues. Some Asian textbooks of English extend the content into some issues related to global warming, other environmental issues such as forest degradation, hunger in the world, human rights, child issues, human trafficking, as well as some issues related to terrorism and civil war in the world.

A growing number of commercially published English textbooks appear which deal with global issues as the topics of the textbooks such as Making Peace by Brooks and Fox, The World Around Us by Hoppenrath and Royal, and The Global Classroom by de Cou-Landberg [1].

For language educators who find difficulties in finding those such type of textbooks, they can create their own teaching materials on wide range of topics related to global issues such as; poverty, modernization, historical sites in the world, peace, human rights, respect. They can also access some online sources related to these issues such as from youtube and some other sites published by English speaking country embassies.

This again and again give more benefits to teachers and students. Especially for the teachers, this will give them more chances to be more independent teachers and improve their positive attitudes toward their surrounding and any new challenged provided for them.

\section{EXTRACURRICULAR ACTIVITIES FOR GLOBAL EDUCATION}

Extracurricular activities can also be used to give students experience and exposure to global issues while learning certain foreign languages. Activities such as seminar on global issues, speech contest or other competition with the topics related to global issues can be part of the project to introduce students to global issues awareness. Another activity which can facilitate students with global view is the international volunteer activity.

Other activities such as overseas tour and exchange programs can be the options. These activities are currently promoted by some foundations and governments. Teachers can motivate students to apply and join those program to give them new window in seeing the world. Those extracurricular activities are intended to introduce students to different perspectives, way of life, cultures, and social conditions [8].

Extracurricular activities have more chances to be better ways to introduce students with the global problems and the response we should show. This is due to the fact that extracurricular activities give students more time to be relaxed and to be the real people. They mostly consider extracurricular activities as time to get relaxed while enjoying their academic life. If these activities are fulfilled with some activities related to global problems and how to respond them, these will turn to be more enlightening activities for them and their future. Thus, maximizing these activities promoting peace and tolerance is important.

\section{TRAINING FOR TEACHERS TO SUPPORT GLOBAL EDUCATION}

In order to be successful in introducing something new to education, teachers need to be well prepared. Teacher training is one of fundamental parts in education. Equipping teachers with the knowledge and view of global issues is also needed so that teachers can be professionals. Teachers can improve their professional development through some seminars, workshops, and short course [1]. By joining those academic activities with the topic related to global issues, teachers can improve their knowledge and experience in the foreign language they are teaching as well as improving their knowledge related to global issues.

In addition to some seminars and workshop activities, teacher can also join teacher training or teacher professional development programs. These activities will enrich their knowledge and skills to develop teaching courses and materials related to the issues of human trafficking, global warming, civil war, oil in the middle-east, forest in tropical countries, and endangered animals, for examples.

Teacher training has been conducted by the government of Indonesia through the Ministry of Education and Culture. However, the effectiveness of the training related to the goal should have more attention. In other words, supervision during the process of teacher training needs to be more greatly emphasize.

Besides, teacher training should be conducted several times during in one academic year. This is for the sake of the effectiveness of the training both for the teacher and for the education in general.

\section{CONCLUSION}

World problems are not only the responsibilities of those directly related to that issues. Those problems are also our responsibilities. Education can be used to build peace in the world. Through education, leaders are created and through education also, those problems can be reduced and even solved. Thus, our work hard as educators is essential for a better world.

English Language Teaching can be adapted to meet the demand of the global conditions. Such worldwide issues can be taken by teachers to be developed more and suited for the teaching materials. This strategy will give students wider knowledge and attention to global problems.

The success of adapting global issues to English Language Teaching is effected by some factors especially the teacher willingness and readiness to deal with the issues by inserting them to the teaching materials. Support from the government to teachers is also a determining factor. Support such as teacher training program is badly needed by the teachers in order to be able to conduct teaching and learning process which reveal world problems and increase students' awareness toward such problems. 


\section{ACKNOWLEDGMENT}

The authors address gratitude to the State University of Semarang, Indonesia for supporting them in publishing this academic paper. Another gratitude goes to the authors' colleagues in the university. This paper is written as an initial step to create further and deeper research related to the global problems and the role of English Language Teaching in responding the problems.

\section{REFERENCES}

[1] K. Cates. "Teaching for a better world," The Language Teacher, vol. $5,1990$.

[2] UNESCO, Recommendation Concerning Education for International Understanding, Cooperation and Peace and Education Relating to Human Rights and Fundamental Freedoms, Paris: UNESCO, 1974.

[3] S. Fisher and D. Hicks, World Studies 8-13: A Teacher's Handbook, Edinburgh: Oliver \& Boyd, 1985.

[4] W. Kniep, "A critical review of the short history of global education," American Forum for Global Education, New York, 1985.

[5] World Confederation of Organizations of Teaching Profession (WCOTP), WCOTP Handbook. Switzerland: WCOTP, 1989.

[6] UNESCO, Linguapax Kiev Declaration on Content and Methods that could Contribute in the Teaching of Foreign Languages and Literacy to International Understanding and Peace, Paris: UNESCO, 1987.

[7] G. Pike and D. Selby, "Global teacher, global learner," London: Hoddor and Stoughton, 1988.
[8] D. Selby, "Global education: Toward a quantum model of environmental education," Canadian Journal of Environmental Education, vol. 4, 1999.

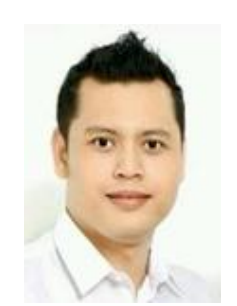

$\mathrm{PhD}$.

He is determined to develop the university by becoming the secretary of Islamic Development Bank (IDB) project at UNNES from 2010 to now. He is also the assistant to vice rector for Development and Collaboration at UNNES. His research mostly focuses on English proficiency, English linguistics and English education.

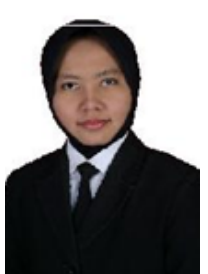

Yuliati is with the Semarang State University (UNNES), Indonesia. She was born in Pekalongan in 1986. She is an English lecturer at the English Department, Languages and Arts Faculty, Semarang State University (UNNES), Indonesia. She holds a master of education in English language teaching from University of Glasgow, UK in 2011. Her research mostly focuses on English as a lingua franca and an international language, English linguistics and English

education.

Hendi Pratama is with Semarang State University (UNNES), Indonesia. He was born in Semarang in Department, Languages and Arts Faculty, Semarang master of art from the University of Queensland ustralia in 2009.

In addition to teaching at UNNES, currently he is also working on Developing the International Collaborations of the University while pursuing his

education. 